\title{
RADIOCARBON AND STABLE ISOTOPE EVIDENCE OF DIETARY CHANGE FROM THE MESOLITHIC TO THE MIDDLE AGES IN THE IRON GATES: NEW RESULTS FROM LEPENSKI VIR
}

\author{
C Bonsall ${ }^{1,2} \bullet \mathrm{G} \mathrm{T} \mathrm{Cook}^{3} \bullet$ R E M Hedges ${ }^{4}$ T F G Higham ${ }^{4} \bullet$ C Pickard ${ }^{1} \bullet$ I Radovanović 5
}

\begin{abstract}
A previous radiocarbon dating and stable isotope study of directly associated ungulate and human bone samples from Late Mesolithic burials at Schela Cladovei in Romania established that there is a freshwater reservoir effect of approximately $500 \mathrm{yr}$ in the Iron Gates reach of the Danube River valley in southeast Europe. Using the $\delta^{15} \mathrm{~N}$ values as an indicator of the percentage of freshwater protein in the human diet, the ${ }^{14} \mathrm{C}$ data for 24 skeletons from the site of Lepenski Vir were corrected for this reservoir effect. The results of the paired ${ }^{14} \mathrm{C}$ and stable isotope measurements provide evidence of substantial dietary change over the period from about 9000 BP to about 300 BP. The data from the Early Mesolithic to the Chalcolithic are consistent with a 2-component dietary system, where the linear plot of isotopic values reflects mixing between the 2 end-members to differing degrees. Typically, the individuals of Mesolithic age have much heavier $\delta^{15} \mathrm{~N}$ signals and slightly heavier $\delta^{13} \mathrm{C}$, while individuals of Early Neolithic and Chalcolithic age have lighter $\delta^{15} \mathrm{~N}$ and $\delta^{13} \mathrm{C}$ values. Contrary to our earlier suggestion, there is no evidence of a substantial population that had a transitional diet midway between those that were characteristic of the Mesolithic and Neolithic. However, several individuals with "Final Mesolithic" ${ }^{14} \mathrm{C}$ ages show $\delta^{15} \mathrm{~N}$ and $\delta^{13} \mathrm{C}$ values that are similar to the Neolithic dietary pattern. Provisionally, these are interpreted either as incomers who originated in early farming communities outside the Iron Gates region or as indigenous individuals representing the earliest Neolithic of the Iron Gates. The results from Roman and Medieval age burials show a deviation from the linear function, suggesting the presence of a new major dietary component containing isotopically heavier carbon. This is interpreted as a consequence of the introduction of millet into the human food chain.
\end{abstract}

\section{INTRODUCTION}

The Iron Gates section of the Danube River valley has an exceptional record of human occupation extending back to the Late Glacial period, about 12,600 BP. It is known especially for a large series of open-air settlements with evidence of Mesolithic and/or Early Neolithic occupation. The most famous of these is the site of Lepenski Vir, which is the focus of this paper (Figure 1). There has long been a debate over the dating of this site. The excavations at Lepenski Vir were conducted between 1965 and 1970 by Dragoslav Srejović, who identified a stratigraphic sequence of 5 occupation phases: Proto-Lepenski Vir (Early Mesolithic), Lepenski Vir I and II (Late Mesolithic), and Lepenski Vir IIIa and IIIb (Early Neolithic) (Srejović 1969, 1972). The results of radiocarbon dating have been inconsistent with this interpretation. A series of charcoal samples from contexts associated with LV I-II buildings gave ${ }^{14} \mathrm{C}$ ages between about 6560 and about $7360 \mathrm{BP}$ (Quitta 1972), which are similar to those for Early Neolithic (Starčevo-Körös-Criş) sites in the surrounding regions (Gimbutas 1991; Radovanović 1996; Whittle et al. 2002). Subsequent accelerator mass spectrometry (AMS) dating of human remains assigned to the later phase, LV III, produced ages between about 6910 and 7770 BP (Bonsall et al. 1997), which are earlier than expected on the basis of the stratigraphic interpretation.

A series of human bone ages from another Iron Gates site, Vlasac, about $2 \mathrm{~km}$ downriver from Lepenski Vir, were also offset from previously measured charcoal ages. The similar trends in these

\footnotetext{
${ }^{1}$ School of Arts, Culture and Environment, University of Edinburgh EH1 1LT, United Kingdom.

${ }^{2}$ Corresponding author. Email: C.Bonsall@ed.ac.uk.

${ }^{3}$ Scottish Universities Environmental Research Centre, East Kilbride G75 0QF, United Kingdom.

Email: g.cook@suerc.gla.ac.uk.

${ }^{4}$ Radiocarbon Accelerator Unit, Research Laboratory for Archaeology and the History of Art, Oxford OX1 3QJ, United Kingdom.

${ }^{5}$ Department of Anthropology, University of Kansas, 616 Fraser, Lawrence, Kansas 66045, USA.
}

(C) 2004 by the Arizona Board of Regents on behalf of the University of Arizona Proceedings of the 18th International Radiocarbon Conference, edited by N Beavan Athfield and R J Sparks RADIOCARBON, Vol 46, Nr 1, 2004, p 293-300 


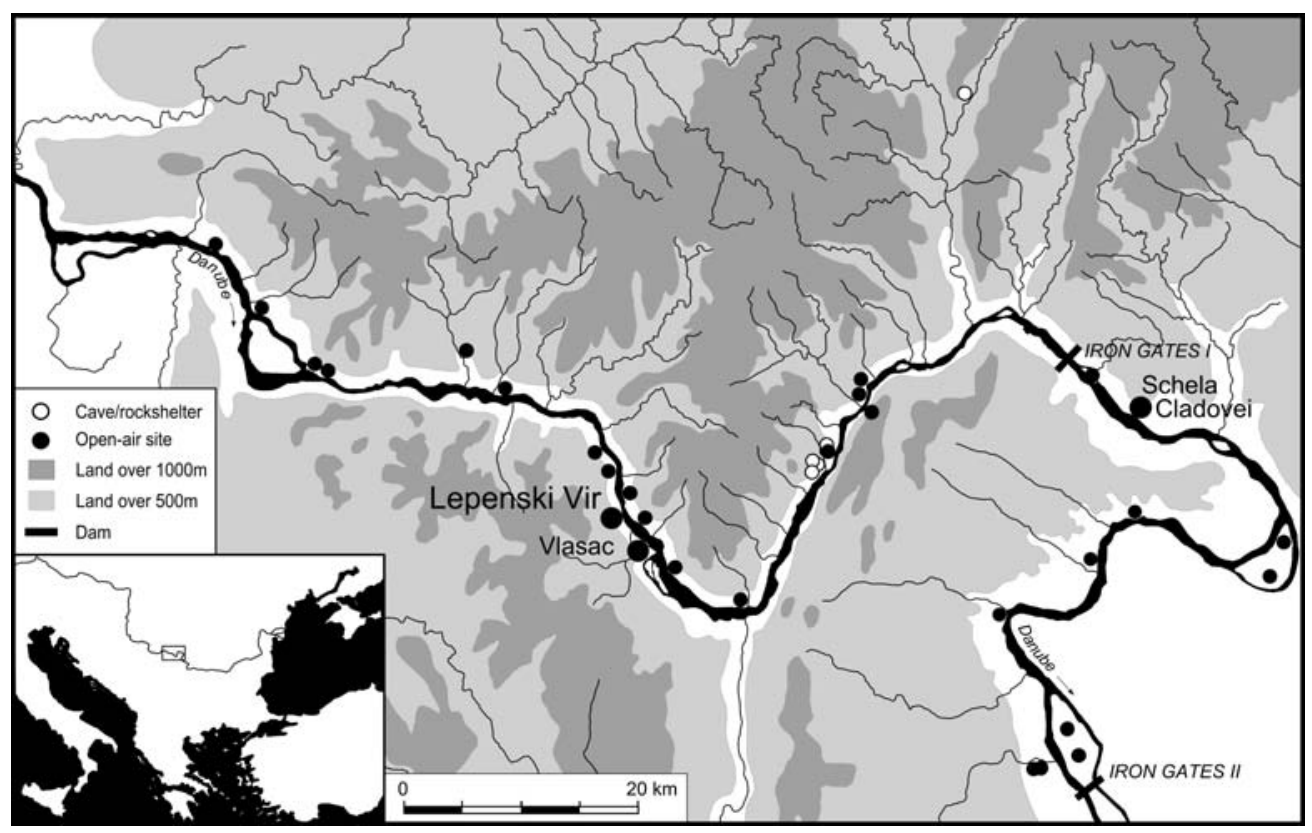

Figure 1 Mesolithic and Early Neolithic sites in the Iron Gates section of the Danube Valley

2 sites raised the possibility that some type of reservoir effect was in operation, making the human bone ages appear too old.

A third Iron Gates site, Schela Cladovei, provided a means of investigating this question. The ${ }^{14} \mathrm{C}$ ages of Late Mesolithic human bones were compared with directly associated ungulate bones, in the form of arrowheads embedded in, or otherwise directly associated with, the human skeletons (Cook et al. 2001, 2002). An age offset was observed between the 2 sample types in which the human bone ages were always several hundred years older than the associated ungulate bone projectile points, implying that the human population was deriving at least part of its diet from a carbon reservoir that was depleted in ${ }^{14} \mathrm{C}$ relative to the contemporaneous atmosphere. Stable isotope analyses $\left(\delta^{13} \mathrm{C}\right.$ and $\delta^{15} \mathrm{~N}$ ) of both sets of samples indicated that the $\delta^{13} \mathrm{C}$ values for the human bones were always slightly heavier than those of the ungulates, while the $\delta^{15} \mathrm{~N}$ values were enriched significantly. These data were compared with published values (e.g. Ambrose 1991; Lanting and van der Plicht 1998; Little and Little 1997) and it was concluded that the human diet must have contained a significant proportion of freshwater fish and, therefore, the River Danube was the source of the reservoir effect. Since virtually all of the nitrogen that humans assimilate is derived from protein (Conn and Stumpf 1972), it was assumed that the $\delta^{15} \mathrm{~N}$ values recorded in the human bone collagen would be the result of a linear mixing of terrestrial and riverine resources. It was postulated that provided one had endmember values for these resources, it should be possible to estimate both the contribution of each resource to the diet and the reservoir age that should be subtracted from any human bone ${ }^{14} \mathrm{C}$ age prior to calibration on the calendar timescale. To achieve this, the following data were used:

1. Human bone samples from 3 individuals, all of which had $\delta^{15} \mathrm{~N}$ values of approximately $+15 \%$;

2. An average offset for these individuals from the ungulate bone ages of $425 \pm 55 \mathrm{yr}$;

3. An assumed $\delta^{15} \mathrm{~N}$ value for the terrestrial diet end-member of $+8 \%$ (based on literature values: Mays 1998; Ogrinc 1999); 
4. An aquatic resources end-member for $\delta^{15} \mathrm{~N}$ of $+17 \%$, based on the heaviest value for an individual from the Iron Gates (Bonsall et al. 1997).

From this, we determined that $+15 \%$ corresponded to a diet with approximately $79 \%$ of aquatic protein, for which the average reservoir age was $425 \pm 55 \mathrm{yr}$. Thus, a reservoir age of $540 \pm 70 \mathrm{yr}$ would be applicable to someone subsisting wholly on riverine resources. This reservoir correction was then applied to the available human bone ages from Lepenski Vir and Vlasac.

Reservoir correction of the previously reported human bone ages from Lepenski Vir (Bonsall et al. 1997) brought the results broadly into the same range as the charcoal ages (Cook et al. 2001), but still in conflict with the stratigraphic dating unless phases LV I-IIIb occupy a very short time-span. In a separate study of the stable isotope data from Lepenski Vir, Bonsall et al. (2000) demonstrated that there was a linear correlation between $\delta^{13} \mathrm{C}$ and $\delta^{15} \mathrm{~N}$ in human bone collagen. The data also implied that there were 3 compositional patterns to the human diet during the time-range represented by the burials - one dominated by aquatic resources, one dominated by terrestrial resources, and a third that was intermediate in character. Furthermore, once the reservoir age appropriate to the diet of individual humans had been subtracted from the age of the human bone samples, the data implied that the diet dominated by aquatic resources was from the Late Mesolithic; the diet dominated by terrestrial resources was from the Early Neolithic; and the intermediate diet was from the Mesolithic/Neolithic transition. However, this conclusion was based on a limited number of ${ }^{14} \mathrm{C}$ age measurements. This paper reports on a much more extensive suite of AMS ${ }^{14} \mathrm{C}$ and associated $\delta^{13} \mathrm{C}$ and $\delta^{15} \mathrm{~N}$ analyses of human bone collagen from Lepenski Vir.

\section{METHODS}

Bone samples were prepared for AMS ${ }^{14} \mathrm{C}$ dating at the Oxford Radiocarbon Accelerator Unit (ORAU) using routine collagen extraction procedures (Bronk Ramsey et al. 2000; Law and Hedges 1989). An additional ultrafiltration pretreatment step was used to further purify the bone gelatin and retain only the $>30-\mathrm{kD}$ molecular weight fraction for ${ }^{14} \mathrm{C}$ assay (Brown et al. 1988; Bronk Ramsey et al. 2000). The $<30-\mathrm{kD}$ fraction may include degraded collagen fragments, salts, and contaminants that may be of a different ${ }^{14} \mathrm{C}$ age to the gelatin. We used the ratio of carbon to nitrogen $(\mathrm{C}: \mathrm{N}$ ratio) to determine the chemical integrity of the extracted gelatin. All ratios were within the 2.9-3.6 range of acceptability for bone collagen used at ORAU. Yields of ultrafiltered gelatin that are below $10 \mathrm{mg} \mathrm{g}^{-1}$ are not dated routinely because they indicate poor levels of collagen preservation. All of the ultrafiltered samples from Lepenski Vir were above this threshold.

The $>30-\mathrm{kD}$ fraction was lyophilized and analyzed using a Europa Scientific ANCA-MS system consisting of a 20-20 IR mass spectrometer interfaced to a Roboprep CHN sample converter unit operating in continuous flow mode. $\mathrm{CO}_{2}$ from the combustion was trapped cryogenically and graphite was prepared by reduction of $\mathrm{CO}_{2}$ over iron within an excess $\mathrm{H}_{2}$ atmosphere. Graphite targets were then measured by AMS (Bronk Ramsey and Hedges 1997). Small samples of $\mathrm{CO}_{2}(<1.6 \mathrm{mg} \mathrm{C})$ were dated directly using the ORAU gas ion source (Bronk Ramsey and Hedges 1997). $\delta^{13} \mathrm{C}$ values in this paper are reported in per mil (\%) with reference to VPDB and $\delta^{15} \mathrm{~N}$ results are reported with reference to AIR (Coplen 1994).

\section{RESULTS AND DISCUSSION}

The data presented here comprise 5 previously published (Bonsall et al. 1997) and 19 new sets of analyses. Table 1 summarizes the reservoir corrected ${ }^{14} \mathrm{C}$ data for the $24 \mathrm{AMS}{ }^{14} \mathrm{C}$ measurements and the number of samples, following this reservoir correction, which can be assigned to the various archaeological periods. Figure 2 summarizes the $\delta^{13} \mathrm{C}$ and $\delta^{15} \mathrm{~N}$ results for all 24 human bone samples. 
Table 1 Phasing of 24 AMS ${ }^{14} \mathrm{C}$-dated skeletons from Lepenski Vir. Reservoir corrected ${ }^{14} \mathrm{C}$ ages were calculated using Method 1 of Cook et al. (2002).

\begin{tabular}{llc}
\hline Reservoir corrected ${ }^{14} \mathrm{C}$ age range & Notional archaeological period & $\mathrm{Nr}$ of samples \\
\hline $9020 \pm 80-8784 \pm 72$ BP & Early Mesolithic & 2 \\
about $8500-7400$ BP & Late Mesolithic & 0 \\
$7374 \pm 80-7133 \pm 75$ BP & Final Mesolithic & 12 \\
$7036 \pm 95-6718 \pm 93$ BP & Early Neolithic (Starčevo) & 5 \\
$5269 \pm 54$ BP & Chalcolithic (Salcuţa) & 1 \\
$1724 \pm 44-339 \pm 38$ BP & Roman and Medieval & 4 \\
\hline
\end{tabular}

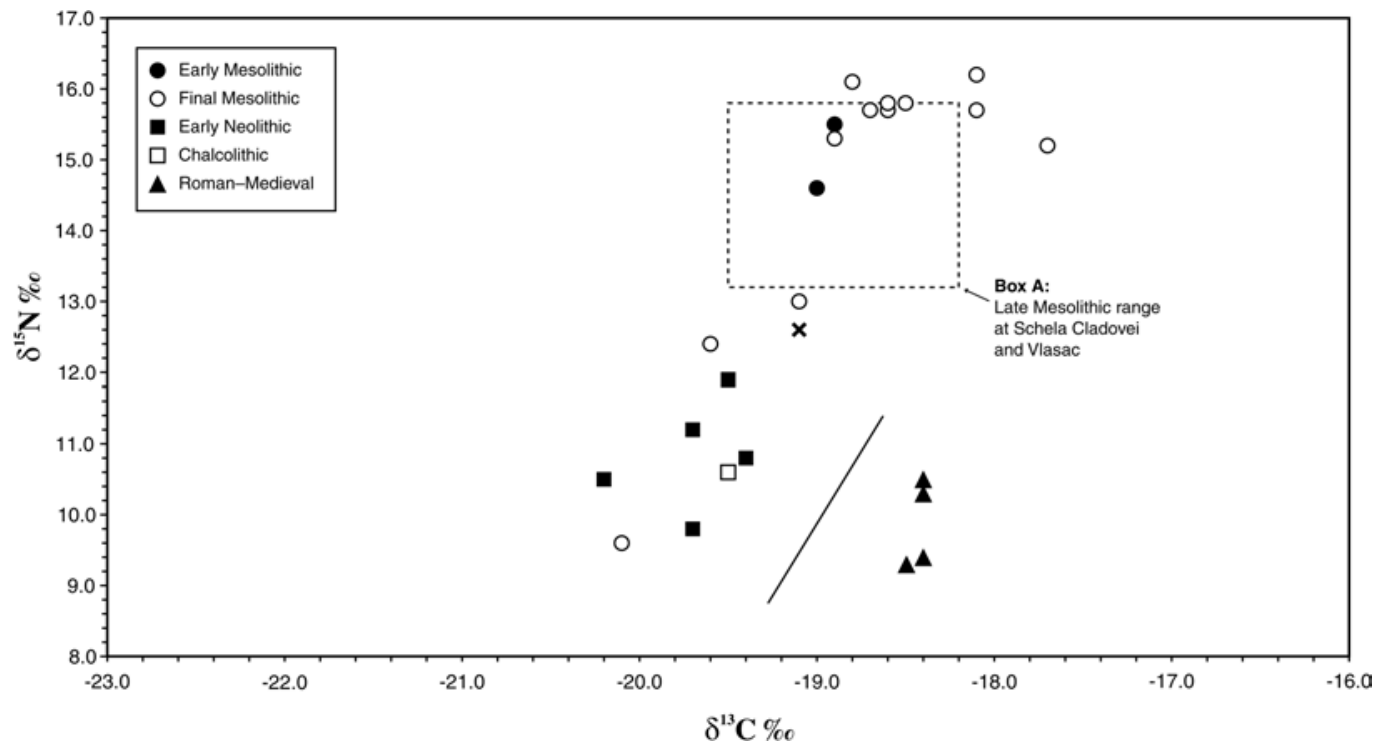

Figure $2 \delta^{13} \mathrm{C}$ versus $\delta^{15} \mathrm{~N}$ for 24 AMS ${ }^{14} \mathrm{C}$-dated human skeletons from Lepenski Vir. The cross $(\mathrm{x})$ represents an undated burial of Starčevo type.

From Table 1, it can be observed that there are no skeletons from Lepenski Vir that are dated to the period 8500-7400 BP ("Late Mesolithic"), but this time range is represented at 2 other sites. At Vlasac, 4 skeletons have been dated between 8400-7600 BP, while at Schela Cladovei, 6 skeletons have been dated between 8100-7700 BP (Bonsall et al. 1997; Cook et al. 2001, 2002). In contrast, the period 7400-7100 BP ("Final Mesolithic") is only represented at Lepenski Vir and not currently at any other site in the Iron Gates region. This appears to have been a period of general site abandonment in the Iron Gates, possibly linked to increased flooding along the Danube which coincided with the "8200 cal BP global cooling event" (Bonsall et al. 2002).

It is interesting to consider the "isotopic profiles" of humans belonging to the different time ranges that are set out in Table 1.

\section{Late Mesolithic (8500-7400 BP)}

This period is considered first because the stable isotope profile of Late Mesolithic populations in the Iron Gates is well known from our earlier research. Ten skeletons from Schela Cladovei and Vlasac have been dated to the time range $8500-7400 \mathrm{BP}$ (Bonsall et al. 1997, 2000). The $\delta^{13} \mathrm{C}$ and $\delta^{15} \mathrm{~N}$ 
values of these 10 skeletons fall within the range circumscribed by Box A in Figure $2, \delta^{13} \mathrm{C}:-19.5$ to $-18.2 \%$ and $\delta^{15} \mathrm{~N}$ : +13.2 to $+15.8 \%$. These values have been interpreted as indicative of diets rich in protein derived from aquatic sources, primarily larger Danube fish such as carp, catfish, and sturgeon (Bonsall et al. 1997).

\section{Early Mesolithic (>8500 BP)}

Two skeletons from Lepenski Vir (and one from Vlasac) are dated to the period before $8500 \mathrm{BP}$ (Figure 2, filled circles). Here, the $\delta^{13} \mathrm{C}$ and $\delta^{15} \mathrm{~N}$ values all fall within the range of Late Mesolithic skeletons from Vlasac and Schela Cladovei (Figure 2, Box A). This suggests that the range defined by Box A is typical for Iron Gates Mesolithic populations older than $7400 \mathrm{BP}$. Using the $\delta^{15} \mathrm{~N}$-based calculation method described in Cook et al. (2001), this is consistent with diets in which $>58 \%$ of the protein was derived from aquatic resources.

\section{Early Neolithic (7100-6700 BP)}

Five skeletons from Lepenski Vir are dated to this time range (Figure 2, filled squares) and have $\delta^{13} \mathrm{C}$ values in the range -20.2 to $-19.4 \%$ and $\delta^{15} \mathrm{~N}$ values of +9.8 to $+11.9 \%$. These values indicate a diet that is very different from that of the Mesolithic populations. It is dominated by terrestrial resources and has a much smaller contribution (20-43\%) from aquatic resources. However, this may underestimate the range of Early Neolithic diets. An undated Starčevo-type burial has more elevated $\delta^{13} \mathrm{C}$ and $\delta^{15} \mathrm{~N}$ values (Figure 2, cross). Thus, we would expect the true $\delta^{15} \mathrm{~N}$ range to be at least +9.8 to $+12.6 \%$, reflecting diets in which $49-80 \%$ of the protein was derived from terrestrial resources. This is consistent with the presence of bones of livestock in Iron Gates sites after about 7100 BP, together with other evidence of a Neolithic farming economy (pottery, bread ovens). Comparison with similar age (Starčevo-Körös-Criş) sites on the Great Hungarian Plain (Whittle et al. 2002), where the majority of dated skeletons have $\delta^{15} \mathrm{~N}$ values in the range +8.3 to $+9.5 \%$, confirms that fishing continued to play a significant role in the Iron Gates economy during this period. This is supported by archaeozoological evidence (Clason 1980; Bartosiewicz et al. 1995).

\section{Final Mesolithic (7400-7100 BP)}

The majority (12) of dated skeletons from Lepenski Vir fall into this time range and show a very broad range of $\delta^{13} \mathrm{C}$ and $\delta^{15} \mathrm{~N}$ values (Figure 2, open circles), much broader than one would expect in a single population with access to the same resources. Nine of the skeletons have very high $\delta^{15} \mathrm{~N}$ values $(+15.2$ to $+16.2 \%)$ and relatively heavy $\delta^{13} \mathrm{C}$ values $(-17.7$ to $-18.8 \%$ ). Although the range of $\delta^{15} \mathrm{~N}$ and $\delta^{13} \mathrm{C}$ values overlaps that of the earlier Mesolithic populations (Figure 2, Box A), on average, both the $\delta^{13} \mathrm{C}$ and $\delta^{15} \mathrm{~N}$ values are heavier. This may reflect either: (1) a higher percentage of aquatic food in the diet, or (2) a change in composition of the aquatic food intake, such as an increase in the average size of fish consumed or concentration on certain species. Possible causes of this change include the following:

- Social - e.g., higher status individuals with preferential access to large fish or certain species.

- Environmental-e.g., effect of increased flooding on fish populations.

- Technological - change in fishing methods resulting in catches of different species or larger specimens.

- A combination of these.

Three skeletons have much lighter $\delta^{13} \mathrm{C}$ and $\delta^{15} \mathrm{~N}$ values. The $\delta^{15} \mathrm{~N}$ values are also lighter than those from any Mesolithic skeletons from either Schela Cladovei or Vlasac. In 2 cases, the $\delta^{15} \mathrm{~N}$ values are intermediate between aquatic and terrestrial diets and similar to the upper end of our "expected" 
Early Neolithic range, while the third has a $\delta^{15} \mathrm{~N}$ value which is lighter than any of the dated Early Neolithic skeletons from Lepenski Vir and similar to values recorded from Starčevo sites on the Hungarian Plain (Whittle et al. 2002), suggesting a diet based on terrestrial food sources. There are several possible explanations for these results:

- The individuals with light or intermediate $\delta^{15} \mathrm{~N}$ values were incomers (e.g. on marriage) whose bone collagen had not undergone complete turnover. The age-at-death profiles of the individuals concerned (Roksandić 1999) are consistent with this interpretation. The individual with the light $\delta^{15} \mathrm{~N}$ value is relatively young (20-40 yr), while the individuals with intermediate $\delta^{15} \mathrm{~N}$ values are older ( $>40 \mathrm{yr}$ ) and would have had longer to adjust. If so, the question is whether these individuals transferred from a hunter-gatherer (Mesolithic) community(-ies) or a farming community(-ies). The only evidence for the existence of hunter-gatherer communities in the northern Balkans with an economy based on terrestrial food sources derives from an age of $8085 \pm 55$ BP (OxA-8504) for a burial from the Starčevo culture site of Topole-Bač in northern Serbia (Whittle et al. 2002). A $\delta^{13} \mathrm{C}$ value of $-19.9 \%$ and a $\delta^{15} \mathrm{~N}$ value of $+8.6 \%$ for this individual indicate a terrestrially-based diet, but the dating is inconsistent with the archaeological evidence. This is one of two crouched inhumations (implying an Early Neolithic age) that were situated back to back (further implying that the burials were more or less contemporaneous). The 2 skeletons have similar $\delta^{13} \mathrm{C}$ and $\delta^{15} \mathrm{~N}$ values; however, the second has a ${ }^{14} \mathrm{C}$ age of $7170 \pm 50 \mathrm{BP}(\mathrm{OxA}-8693)$, which is consistent with the archaeological context. Thus, the ${ }^{14} \mathrm{C}$ age of the first skeleton requires verification. If individuals with light/intermediate $\delta^{15} \mathrm{~N}$ values in the Final Mesolithic group are "incomers", they are more likely to be derived from Early Neolithic farming communities. There is no unequivocal evidence that farming was practiced anywhere in the Middle or Lower Danube Basin (outside the Iron Gates) during the period 7400-7100 BP. However, by about 7300 BP, Neolithic communities were present in the Morava valley, about $120 \mathrm{~km}$ southwest of Lepenski Vir (Whittle et al. 2002).

- The ${ }^{14} \mathrm{C}$ ages lie at the lower extremes of the $2-\sigma$ ranges, and these skeletons belong to the later part of the time-range (about 7250-7100 BP), when agriculture began to make a significant contribution to diet. That is, the burials are those of indigenous people who represent the earliest Neolithic of the Iron Gates. The implication of this hypothesis is that the transition to farming occurred as early as, or earlier than, elsewhere in the Danube Basin. This is in conflict with the view espoused by some authors (e.g. Radovanović and Voytek 1997) that the transition in the Iron Gates was significantly delayed compared to neighboring regions such as the Great Hungarian Plain, where the earliest ${ }^{14} \mathrm{C}$ ages for short-lived terrestrial material from Early Neolithic (Starčevo-Körös) contexts are about 7100 BP (Whittle et al. 2002). If the 3 individuals with light/intermediate $\delta^{15} \mathrm{~N}$ values do belong to the earliest Neolithic, it is interesting that the burial rite in each case follows the Mesolithic tradition of extended supine inhumation, rather than the crouched or tightly flexed inhumation rite of the Early Neolithic (Starčevo culture).

- A third hypothesis - a variant on hypothesis 2, above - is that the lifetimes of the individuals with light/intermediate $\delta^{15} \mathrm{~N}$ values overlapped with a short-lived phase(s) when terrestrial food resources became (temporarily) more important in the Iron Gates economy. It is possible that in the relatively "difficult" environment of the Danube gorges, there were one or more "false starts" to agriculture, lasting years to decades. Under these circumstances, the people might be forced to revert to the traditional Mesolithic subsistence pattern, based on aquatic resources, before a farming economy was successfully established about $7100 \mathrm{BP}$.

It is not possible to decide between the above hypotheses on present evidence; however, analysis of $\mathrm{Sr}-, \mathrm{Pb}-$, and $\mathrm{O}$-isotopes in teeth might indicate whether the individuals with light/intermediate $\delta^{15} \mathrm{~N}$ values originated outside the Iron Gates (e.g. Budd et al. 2001; Price et al. 2001). An implication 
common to all the hypotheses is that the Lepenski Vir population had knowledge of agriculture, regardless of whether they practiced it prior to $7100 \mathrm{BP}$.

\section{Chalcolithic (Eneolithic)}

One skeleton from Lepenski Vir (Figure 2, open square) was assigned to the Chalcolithic (Salcuţa culture) on archaeological grounds (Zoffmann 1983). This dating is confirmed by the reservoir corrected ${ }^{14} \mathrm{C}$ age of $5269 \pm 54 \mathrm{BP}$. It is interesting that the $\delta^{13} \mathrm{C}$ and $\delta^{15} \mathrm{~N}$ values fall within the range of the Early Neolithic skeletons, suggesting a similar diet, i.e., one dominated by terrestrial resources with low to moderate levels of aquatic protein.

\section{Roman and Medieval Periods}

One individual is dated to the Roman period and 3 to the Medieval period (Figure 2, filled triangles). Like the Early Neolithic and Chalcolithic skeletons, these individuals have light $\delta^{15} \mathrm{~N}$ values $(+9.3$ to $+10.5 \%$ ), but they are unusually enriched in ${ }^{13} \mathrm{C}\left(\delta^{13} \mathrm{C}:-18.5\right.$ to $\left.-18.4 \%\right)$. The most likely explanation is the incorporation of $\mathrm{C}_{4}$ plant material into the food chain (Bonsall et al. 2000). There is evidence that millet started to be grown in this part of southeast Europe during the Iron Age (Murray and Schoeninger 1988) and its addition into the human diet, either directly or indirectly in the form of forage fed to livestock, would result in enrichment in $\delta^{13} \mathrm{C}$ without enriching the $\delta^{15} \mathrm{~N}$ values.

\section{CONCLUSIONS}

The results of paired ${ }^{14} \mathrm{C}$ and stable isotope measurements on 24 skeletons from Lepenski Vir provide evidence of substantial dietary change over the period from about 9000 BP to about 300 BP. The data from the Early Mesolithic to the Chalcolithic are consistent with a 2-component dietary system, where the linear plot of isotopic values reflects mixing between the 2 end-members to differing degrees. Typically, the individuals of Mesolithic age have much heavier $\delta^{15} \mathrm{~N}$ signals and slightly heavier $\delta^{13} \mathrm{C}$, while individuals of Early Neolithic and Chalcolithic age have lighter $\delta^{15} \mathrm{~N}$ and $\delta^{13} \mathrm{C}$ values. Contrary to Bonsall et al. (2000), there is no evidence of a substantial population that had a transitional diet midway between those that were characteristic of the Mesolithic and Neolithic. However, several individuals with "Final Mesolithic" ${ }^{14} \mathrm{C}$ ages show $\delta^{15} \mathrm{~N}$ and $\delta^{13} \mathrm{C}$ values that are similar to the Neolithic dietary pattern. Provisionally, these are interpreted either as incomers who originated in early farming communities outside the Iron Gates region or as indigenous individuals representing the earliest Neolithic of the Iron Gates region. The results from Roman and Medieval age burials show a deviation from the linear function, suggesting the presence of a new major dietary component containing isotopically heavier carbon. This is interpreted as a consequence of the introduction of millet into the human food chain.

\section{REFERENCES}

Ambrose SH. 1991. Effects of diet, climate and physiology on nitrogen isotope abundances in terrestrial foodwebs. Journal of Archaeological Science 18:293317.

Bartosiewicz L, Bonsall C, Boroneanţ V, Stallibrass S. 1995. Schela Cladovei: a preliminary review of the prehistoric fauna. Mesolithic Miscellany 16(2):2-19.

Bonsall C, Lennon R, McSweeney K, Stewart C, Harkness D, Boroneanţ V, Payton R, Bartosiewicz L, Chapman JC. 1997. Mesolithic and Early Neolithic in the Iron Gates: a palaeodietary perspective. Journal of European Archaeology 5(1):50-92.
Bonsall C, Cook G, Lennon R, Harkness D, Scott M, Bartosiewicz L, McSweeney K. 2000. Stable isotopes, radiocarbon and the Mesolithic-Neolithic transition in the Iron Gates. Documenta Praehistorica 27:119132.

Bonsall C, Macklin MG, Payton RW, Boroneanţ A. 2002. Climate, floods and river gods: environmental change and the Meso-Neolithic transition in southeast Europe. Before Farming: The Archaeology of Old World Hunter-Gatherers 3-4(2):1-15.

Bronk Ramsey C, Hedges REM. 1997. Hybrid ion sources: radiocarbon measurements from microgram 
to milligram. Nuclear Instruments and Methods in Physics Research B 123:539-45.

Bronk Ramsey C, Pettitt PB, Hedges REM, Hodgins GWL, Owen DC. 2000. Radiocarbon dates from the Oxford AMS system: Archaeometry Datelist 30. Archaeometry 42(2):459-79.

Brown TA, Nelson DE, Vogel JS, Southon JR. 1988. Improved collagen extraction by modified Longin method. Radiocarbon 30(1):171-7.

Budd P, Montgomery J, Evans J, Chenery C. 2001. Combined $\mathrm{Pb}$-, $\mathrm{Sr}$ - and $\mathrm{O}$-isotope analysis of human dental tissue for the reconstruction of archaeological residential mobility. In: Holland JG, Tanner SD, editors. Plasma Source Mass Spectrometry: The New Millennium. Cambridge: Royal Society of Chemistry Special Publication. p 311-26.

Clason AT. 1980. Padina and Starčevo: game, fish and cattle. Palaeohistoria XXII:142-73.

Cook GT, Bonsall C, Hedges REM, McSweeney K, Boroneant V, Pettitt PB. 2001. A freshwater diet-derived ${ }^{14} \mathrm{C}$ reservoir effect at the Stone Age sites in the Iron Gates gorge. In: Carmi I, Boaretto E, editors. Proceedings of the 17th International Radiocarbon Conference, Judean Hills, Israel, 18-23 June 2000. Radiocarbon 43(2A):453-60.

Cook GT, Bonsall C, Hedges REM, McSweeney K, Boroneanţ V, Bartosiewicz L, Pettitt PB. 2002. Problems of dating human bones from the Iron Gates. Antiquity 76:77-85.

Coplen TB. 1994. Reporting of stable hydrogen, carbon and oxygen isotopic abundances. Pure and Applied Chemistry 66:273-6.

Gimbutas M. 1991. The Civilization of the Goddess: The World of Old Europe. San Francisco: Harper.

Hedges REM, Law IA, Bronk CR, Housley RA. 1989. The Oxford accelerator mass spectrometry facility: technical developments in routine dating. Archaeometry 31:99-113.

Lanting JN, van der Plicht J. 1998. Reservoir effects and apparent ${ }^{14} \mathrm{C}$ ages. Journal of Irish Archaeology IX: 151-65.

Law IA, Hedges REM. 1989. A semi-automated bone pretreatment system and the pretreatment of older and contaminated samples. Radiocarbon 31(2):247-53.

Little JDC, Little EA. 1997. Analysing prehistoric diets by linear programming. Journal of Archaeological Science 24:741-7.

Mays S. 1998. The Archaeology of Human Bones. London: Routledge.

Murray M, Schoeninger M. 1988. Diet, status and complex social structure in Iron Age Central Europe: some contributions of bone chemistry. In: Gibson DB, Geselowitz MN, editors. Tribe and Polity in Late Prehistoric Europe: Demography, Production and Exchange in the Evolution of Complex Social Systems. New York: Plenum. p 155-76.

Ogrinc N. 1999. Stable isotope evidence of the diet of the Neolithic population in Slovenia - a case study: Ajdovska jama. Documenta Praehistorica 26:193-200.

Price T, Bentley R, Luning J, Detlef G, Wahl J. 2001. Prehistoric human migration in the Linearbandkeramik of central Europe. Antiquity 75:593-603.

Quitta H. 1972. The dating of radiocarbon samples. In: Srejović D. Europe's First Monumental Sculpture. New Discoveries at Lepenski Vir. London: Thames and Hudson. p 205-10.

Radovanović I. 1996. Mesolithic/Neolithic contacts: a case of the Iron Gates region. Poročilo o raziskovanju paleolitika, neolitika in eneolitika v Sloveniji 23:3948.

Radovanović I, Voytek B. 1997. Hunters, fishers and farmers: sedentism, subsistence and social complexity in the Djerdap Mesolithic. Analecta Praehistorica Leidensia 29:19-31.

Roksandić M. 1999. Transition from Mesolithic to Neolithic in the Iron Gates Gorge: Physical Anthropology Perspective [ $\mathrm{PhD}$ dissertation]. Burnaby, Canada: Simon Fraser University.

Srejović D. 1969. The roots of the Lepenski Vir culture. Archaeologia Iugoslavica 10:13-21.

Srejović D. 1972. Europe's First Monumental Sculpture. New Discoveries at Lepenski Vir. London: Thames and Hudson.

Whittle A, Bartosiewicz L, Borić D, Pettitt P, Richards M. 2002. In the beginning: new radiocarbon dates for the Early Neolithic in northern Serbia and southeast Hungary. Antaeus 25:64-117.

Zoffmann Z. 1983. Prehistorical skeletal remains from Lepenski Vir (Iron Gate, Yugoslavia). Homo 34:12948. 